\title{
Analysing a non-IR field through IR lenses. Education in post-conflict Kosovo
}

\author{
Ervjola Selenica (it) \\ Scuola Normale Superiore, Pisa, Italy \\ Corresponding author. Email: ervjola.selenica@sns.it
}

(Received 6 February 2021; revised 1 November 2021; accepted 2 November 2021; first published online 1 December 2021)

\begin{abstract}
The paper argues that education is relevant for both domestic and international reasons and without an incorporation of the international within the national it is not possible to understand education's changes and transformations in post-conflict and conflict-affected contexts. The paper aims to connect the local to the global by investigating their dynamic interaction through the peculiar lenses of international assistance to education reform in post-conflict Kosovo. It asks two questions: (1) how do global agendas of peace and security affect education reforms in conflict-affected contexts? and (2) how does education reform in conflict-affected contexts interacts with and is related to broader, international dynamics, processes, and actors? More specifically, the paper analyses the role of international actors in traditionally national sectors and the multi-layered, hybrid governance of education reform within a broader statebuilding, peacebuilding, and stabilization perspective. The analysis is divided into two empirical instances: (i) education for liberal multicultural peace (1999-2013) and (ii) education against violent extremism and radicalization (2014-2019). The paper sheds light on the globalization and securitization of education as well as the changing forms and practice of statehood and sovereignty in times of post-war-reconstruction and fragility. A threat-containment and security-based logic has dictated priorities and determined choices in education reform and content.
\end{abstract}

Key words: Education; global governance; IR; Kosovo; peacebuilding; violent extremism

\section{Introduction}

This paper argues that education in ethno-national and post-conflict contexts is relevant for both national and international reasons, and without an incorporation of the international within the domestic, it is not possible to understand education's changes and transformations in postconflict settings. In line with other papers from the Special Issue (Dian, 2021; Raineri and Baldaro, 2021), the paper aims to connect the local to the global and investigate the dynamic interaction between the two through the peculiar and under-analysed lenses of education reform in post-conflict international interventions. The paper asks the following two questions: (1) how do global agendas of peace and security affect education reforms in conflict-affected contexts?; and (2) how does education reform in conflict-affected contexts interacts with and is related to broader, international dynamics, processes, and actors? In order to address both questions, the paper uses post-conflict Kosovo as a case study that traces the changing relationship between international interventions and education across 20 years. The time frame chosen allows grasping changes both in the international system and in global agendas of peace and security and how they are reflected upon and translated in education reform.

The paper analyses externally led education reform in Kosovo, a sector considered by International Relations (IR) theories and scholars as a national prerogative thus fundamentally

(C) The Author(s), 2021. Published by Cambridge University Press on behalf of the Società Italiana di Scienza Politica. This is an Open Access article, distributed under the terms of the Creative Commons Attribution licence (https://creativecommons.org/licenses/by/4.0/), which permits unrestricted re-use, distribution, and reproduction in any medium, provided the original work is properly cited. 
overlooked and ignored, whose governance and changes both at the global and local levels contribute to shed light on many key concepts and processes that have dominated the IR discipline since the end of the Cold War. Despite three decades of international and global processes that have permeated education in conflict-affected and post-conflict contexts, IR continues to be silent and oblivious with regards to the role of global dynamics and the international system in national education and vice versa. In particular, in this paper, I aim to analyse how education is being reconstructed and rebuilt through international agendas and interventions in post-conflict Kosovo and what this can tell us about the relationship between international dynamics and local processes in a globalized world.

The paper explores this interaction between the local and the global through a double peripherality lenses, that is, a peripheral subject in IR scholarship such as education in a peripheral region such as Kosovo, and it aims to contribute theoretically and methodologically to the interaction between IR and Area Studies as argued by this Special Issue.

In light of this Special Issue's expectations, the findings in this paper suggest the importance of incorporating sectors such as education as key dimensions for understanding and grasping change in the international system. The paper highlights the need for studying the global, international, regional, and local as co-constitutive rather than as separate layers, as this Special Issue addresses in a number of papers (Dian, 2021; Raineri and Baldaro, 2021).

The case study analysed finds that education reform and assistance as part of contemporary processes of state formation in peripheral regions are dialectally related and shaped by substantial forms of international interventions and are thus central to contemporary international dynamics. The analysis proposed here suggests that the borders between what is internal from what is international are continuously shifted and negotiated through processes of globalization, international interventionism, and new forms of internationally driven education assistance. Thus, education should not be overlooked in IR since education agendas can be shaped and influenced by international dynamics, agendas, and actors and this is sharply visible and tangible in post-war Kosovo.

Theoretically, the analysis is based upon critical cultural political economy and genealogical historical narrative (Bevir, 2008; Robertson and Dale, 2015). The critical cultural political economy analytical framework places education in the broader socio-economic and political structures, institutions, and agents that affect and constrain it (Robertson and Dale, 2015). It also stresses the importance of politics and policy in shaping the governance frameworks, institutional arrangements, and outcomes of education in conflict-affected contexts (Novelli et al., 2014). The genealogical approach critically historicises the evolution of the education's role and functions in the Kosovo conflict as well as its intertwinement with conflict and peace dynamics. In looking at education as a complex (more than a) system, the category of 'education ensemble' as used by Robertson and Dale (2015) is particularly useful for this paper. They urge to see the 'education ensemble'

As a complex collective, construction of the social world, that is not reducible to schools, or universities, learners and teachers. [...] Education involves an array of actors and other institutions, [...] whose logics, interests and forms of authority generate tensions and contradictions within the ensemble. [...] Education is the outcome of sets of ideas and activities accredited over generations, which, whilst individually irreducible to each other, can be seen to be in an internal relationship with each other in the production of the ensemble. [...] there can be no understanding of the individual elements of the ensemble, without an overall understanding of it (Robertson and Dale, 2015: 155-156).

The broader concept of 'ensemble' is useful in that it places education in multiple relationships with(in) societies and it allows detecting the range of relationships within education and between education and the broader society. 
As methods for data collection, the paper draws on case study analysis, textual analysis of key official documents, and policy reports from the Kosovo Government, the Ministry of Education, Science and Technology, and main international actors that have been engaged with education reform. Furthermore, the paper relies on primary data collected in Pristina throughout November 2013 and September 2018 through 10 semi-structured interviews, respectively. ${ }^{1}$ Key national and international actors that were interviewed in Kosovo in the two respective fieldworks were grouped into three categories: (1) main international actors such as UN Children's Fund (UNICEF), the Organization for Security and Co-operation in Europe (OSCE), the European Union (EU), the Deutsche Gesellschaft für Internationale Zusammernarbeit (GIZ), and bilateral partners such as the US Embassy; (2) government officials within the Ministry of Education; and (3) representatives from the non-governmental organization (NGO)/civil society arena, activists, and opposition parties.

In order to analyse post-war education reform in Kosovo and how the sector is embedded in international dynamics and agendas, the paper is structured as follows. The first three sections aim to locate education within broader processes of globalization, international interventions, and peace and security agendas with the aim of identifying knowledge gaps and bridging different theoretical discussions. The first section reviews debates on the globalization of education. The second section analyses the relationship between education, conflict, and peacebuilding interventions. The third section explores the growing securitization of the education sector as it is incorporated into national, regional, and global policies and agendas of counterterrorism, countering violent extremism (CVE), and counter-radicalization. The fourth section provides a background of the relationship between education and conflict in the Kosovo context. The fifth section unpacks and explores some of the theoretical debates exposed in the previous sections through the empirical case study analysis of post-war education reconstruction, reform, and assistance in post-conflict Kosovo by focusing on international agendas and actors. This section is analytically and chronologically divided into two instances - education for peace between 1999 and 2013 and education against violent extremism between 2014 and 2019 - whose priorities, as the analysis finds, are underpinned by international security imperatives reflecting broader changes in international agendas of intervention. Finally, the paper connects some of the theoretical debates discussed with the empirical analysis and put forth theoretical and methodological reflections in line with the objectives of this Special Issue.

\section{Education and the nation state in a globalized world}

Education has been a core prerogative of the modern nation state. Education is central to the imagining of the national community (Anderson, 1991), the building of its citizenship and labour force for the national economy (Dale, 1989), as well as the consolidation of social cohesion. The historical congruence between nation-state formation and the spreading of public education programmes has been challenged by globalization and war- and state-making processes, which have resulted in various forms of hybrid and global governance that pose a limit to the autonomy and sovereignty of the state (Dale, 1999; Duffield, 2008; Selenica, 2018).

The present paper argues that the consolidated nexus between education and the state that one observes during the process of Western state formation is evolving, and that one can observe this change by studying new states such as Kosovo emerging out of wars in the 21 st century.

In the past decade, a growing number of scholars of comparative sociology and development studies have focused on education and global governance, analysing the increasingly global nature of education agenda-setting and policy-making/implementation (Verger et al., 2012). ${ }^{2}$ They have, in particular, started to address the gaps inherent in the mainstream comparative education

\footnotetext{
${ }^{1}$ All interviews were conducted in confidentiality, and the names of interviewees are withheld by mutual agreement.

${ }^{2}$ The development of education policies and agendas at the international, global, supra-national levels and their diffusion into the local level has been defined within the field of comparative education in many ways such as '[p] olicy borrowing, policy transfer, policy travelling, isomorphism or convergence' (Verger et al., 2012: 3).
} 
literature by seeking to critically analyse the reasons, factors, and agents behind the globalization of education policy, and the ways, structures, and events through which a global education policy agenda is being constituted at the supra-national level while being contextualized at the local level (Verger et al., 2012; Robertson and Dale, 2015; Sobe 2015). Here, particular emphasis is laid on the role of international organizations (IOs) and other political (state or non-state) actors to shape and disseminate education policies globally and the ways through which local contexts reply, comply, or resist such policies. Underpinning this recent critical research is the broader idea that '[p] rocesses of globalisation have drastically altered the education policy landscape across the world and, more particularly, in the context of developing countries' (Verger et al., 2012: 4). Developing countries and their policy landscapes are highly penetrated by global agendas given their substantial dependency on aid, foreign expertise, and information (Rose, 2007). In such countries, the multiplicity of international non-governmental organizations (INGOs), IOs, and donor agencies have the material and ideational capacities to set agendas and priorities.

The relationship between global education policies and national education systems and the effects of globalization on education have been analysed by neo-institutionalist approaches (i.e. 'World Society' Theory) and international political economy approaches (i.e. 'Globally Structured Agenda for Education'). Education, in the view of world society scholars, is a key sector for national governments to show to the international community that they are building a modern nation-state (external legitimacy), whose building and provision contributes to the consolidation of an internal type of legitimacy vis-à-vis their own constituencies. Expanding schooling is part of conforming and converging to world models of the organization of sovereignty (Verger et al., 2012: 11). The main point of World Society scholars is that the state is an exogenously constructed entity (Verger et al., 2012: 12).

By contrast, for political economy approaches, the world capitalist economy is the driving force behind globalization, and economic globalization (and the related competitive pressure) is the main driving force behind the transformations occurring in education (Dale, 2000). As mentioned above, globalization has altered the problems faced by nation-states and their capacity to respond to them (Dale, 2000). It can be seen as a political force, which indirectly affects education by altering the structural conditions within which education change and reform take place (Verger et al., 2012: 13). Such approaches bring to the fora the changing nature of state sovereignty by showing how fundamental education policies are being taken by international or transnational networks and organizations beyond the control of democratically elected institutions (Verger et al., 2012).

Common to this range of diverse comparative education perspectives is the emphasis put on the globalizing effects on education policy and practice. However, by over-emphasizing globalization as the driving factor behind most of the national educational reforms and changes, they have overlooked equally relevant processes such as civil war, secessionism, and international interventions of peacebuilding that do shape education in conflict-affected and post-conflict contexts. Therefore, using a 'globalization/globalizing' lens - while shedding light on international dynamics shaping education in a globalized world - is not enough for understanding the reform of education, its changing forms and functions, and the transformation of its liaisons with the nation state if broader processes of post-conflict reconstruction and international intervention are not incorporated into the analysis. However, as the next section will show, scholarly contributions reviewing statebuilding and peacebuilding processes have only superficially touched upon the issue of education, relegating its role in the post-war peacebuilding architecture as one among several social services that needs to be re-established and provided. The paper aims to contribute to the missed conversation between these different strands of scholarship and thus bridge different theoretical perspectives in order to show how education is at the centre of international dynamics. It aims to pave the way to the establishment of a critical and interdisciplinary research agenda that put at the centre of IR scholarship a sector that may contribute to illuminate broader shifts and changes in the international system. Through the peculiar angle of education in post- 
conflict Kosovo, the paper contributes to and sheds light on national and international processes and dynamics. It shows how the national is dialectically shaped by and linked to the international. At the national level, the paper shows that in post-conflict and conflict-affected contexts, the historically symbiotic relationship between education and the state is changing and being challenged by international dynamics, processes, and actors.

\section{Education, conflict, and international interventions}

One of the most profound changes of the post-Cold War phase is the conceptualization of civil wars as a threat to international peace and security paving the way to a new era of liberal interventionism. This re-conceptualization had an impact on both the practice and discipline of IR. The UN launched an ambitious agenda for tackling increasing instabilities and global challenges such as internal armed conflicts along the world peripheries (Boutros-Ghali, 1992). Initially focusing on ending the war, the frequent relapse into armed violence pushed the UN and the international community to focus increasingly on addressing root causes of war. This was translated in the incorporation of peacekeeping missions into complex peacebuilding operations whose aim was the prevention of conflict and the construction of a sustainable and durable peace and which came to be known as liberal peace ${ }^{3}$ (Boutros-Ghali, 1992; Paris, 1997, 2004).

The Balkans, and more specifically Kosovo, served as a laboratory to test most of the ideas and policies behind the liberal peace agenda and also trace its evolution and changes. Following the 78-day NATO bombing campaign that ended the war in Kosovo the UN Security Council established, in June 1999, the United Nations Interim Administration Mission in Kosovo (UNMIK) through Security Council Resolution 1244, considered as the most ambitious peacebuilding mission in UN history. ${ }^{4}$ The international intervention in Kosovo represented the highest peak of international commitment in war-torn societies. What makes it different from previous peacebuilding missions is the inclusion as part of the international administration of a national sector such as education traditionally falling out of the scope and mandate of international actors (Selenica, 2018).

Although a conspicuously multi-spatial and multi-level engagement of international actors in the education reform of post-conflict and conflict-affected contexts can be observed, education is still a marginal if not absent topic from IR, peacebuilding, and statebuilding scholarship (Novelli and Smith, 2011; Selenica, 2018). Critical peacebuilding scholarship has been more careful in unravelling and grasping local agency and in providing with alternative accounts to the liberal peace agenda and to its templates. However, it has failed to account for the place and role of education in peacebuilding or to recognize the marginalization of education within peacebuilding practice and theory (Selenica, 2018).

By contrast, a range of 'education and conflict' scholarship has investigated and highlighted the complex and multiple ways in which education can potentially contribute to sustainable peace and development in post-conflict settings, for example by addressing conflict root causes, increasing state legitimacy, fostering social cohesion and change, building inclusive citizenship, and contributing to social justice (McCandless, 2011; Novelli and Smith, 2011;Novelli et al., 2017; Selenica, 2018).

In the 1990s, education became increasingly a focus of scholars and practitioners working on the conflict-development nexus. Initially focusing on 'education in emergencies and

\footnotetext{
${ }^{3}$ Liberal peace consisted of a series of reforms that were implemented and transplanted in post-conflict countries regardless of the specific context, comprising at the political level democratization and free elections and at the economic level liberalization, marketization, and privatization, while also prioritizing security sector reform, free media, and human rights at the expense of other overlooked social sector and locally grounded reforms (Paris and Sisk, 2009; Richmond, 2011; Visoka and Musliu, 2020).

${ }^{4}$ According to the UN, UNMIK's 'task was unprecedented in complexity and scope; the Council vested UNMIK with authority over the territory and people of Kosovo, including all legislative and executive powers and administration of the judiciary' (https://peacekeeping.un.org/en/mission/unmik, last accessed 20 October 2021).
} 
humanitarian responses', by the late 1990s, scholars and practitioners increasingly focused on the relationship between education and conflict, or as Bush and Saltarelli (2000) put it, the two faces of education in ethnic conflicts. The seminal work had the merit to bring to the attention of the international community the ways in which education could both exacerbate conflict causes through discrimination and perpetuation of injustices as well as address conflict root causes through the building of an inclusive citizenship and the fostering of tolerance and social cohesion (Bush and Saltarelli, 2000). By the early 2000s, the focus shifted towards the complex role that education plays in peacebuilding processes (World Bank, 2005; Paulson, 2008; Novelli and Smith, 2011).

The multi-scalar international commitment to education that one can observe in peacebuilding interventions is to be understood as part of a larger and more substantial change (one may say erosion) of the symbiotic relationship that historically exists between the state and education as mentioned in the previous section. Moreover, such erosion is supported and complemented by discursive practices that define post-conflict and conflict-affected states as failed, weak, fragile entities, unable to provide/deliver basic services to their population - and thus being disqualified from sovereignty. Failed states have been conceptualized as a global security risk and terrorists' safe havens following the 9/11 attacks and the Global War on Terror. This has entailed an incorporation of education into global security agendas as the next section will address.

\section{The securitization of education in counter-terrorism, counter-radicalization, and countering violent extremism}

Since the 9/11 attacks and the Madrid and London bombing in 2004 and 2005 respectively, and increasingly following the emergence of ISIS in Syria and Iraq in 2014, terrorism, violent extremism, and radicalization have become key concerns for international and national agendas and policies (Kundnani and Hayes, 2018). At the supranational, international, and national levels, a discursive and policy shift from a focus on terrorism to a growing one on violent extremism and radicalization can be observed over the last 15 years, with the terms used interchangeably.

The UN, together with a substantial range of international, regional, and national state and non-state actors is engaged in promoting CVE and de-radicalization programmes across the global North and South and more recently in conflict-affected settings (Novelli, 2017; Kundnani and Hayes, 2018; Selenica, 2019; Martini, 2021). In the UN Plan of Action to Prevent Violent Extremism, the former UN Secretary-general states that:

[t]here is no single pathway to violent extremism. But we know that extremism flourishes when human rights are violated, political space is shrunk, aspirations for inclusion are ignored, and too many people - especially young people - lack prospects and meaning in their lives (UN, 2016).

The Plan, among other actions and priorities, has integrated 'youth's participation, leadership and empowerment as core to the United Nations strategy and responses' (UN, 2015: 2). Furthermore, with the aim of fostering dialogue and preventing conflict, it has also included 'Education, skills development and employment' as one of the seven action areas (UN, 2016). According to the UN Plan, education can efficiently counter terrorism and violent extremism by equipping students with cognitive skills that underpin critical thinking, behavioural, and socioeconomic skills for peaceful existence, tolerance, and respect for human rights, as well as by building educator's capacities to support this educational agenda for CVE (UN, 2016).

Education's incorporation into CVE and counter-radicalization is the result of the abovementioned shift from terrorism to radicalization and violent extremism and the growing incorporation, next to security-based law enforcement measures, of soft-societal measures that target social actors and sectors such as education, youth, and local minority communities within the 
EU and beyond (Novelli, 2017; Ragazzi, 2017; Selenica, 2019). The 'all societal' approach to terrorism, radicalization, and violent extremism, which entails and envisage the participation of a range of societal actors in counter-terrorist and CVE policies, can be seen also in the Youth, Peace, and Security Agenda adopted in 2015, in which the UN Security Council called for states:

[t]o engage relevant communities and non-governmental actors in development strategies to counter the violent extremist narrative that can incite terrorist acts, address the conditions conducive to the spread of violent extremism, which can be conducive to terrorism, including by empowering youth, families, women, religious, cultural and education leaders, and all other concerned groups of civil society and adopt tailored approaches to countering recruitment to this kind of violent extremism and promoting social inclusion and cohesion (UN, 2015: 5).

Scholars have started to stress the increased securitization of education in conflict-affected and fragile contexts as seen by education's incorporation into national and international strategies of counter-radicalization, counter-terrorism, and CVE (Novelli, 2017; Selenica, 2019). A number of critical scholars have emphasized that the incorporation of social sectors and actors such as education, teachers, students, health workers, and minority communities within EU and EU member states policies has come as a result of the shift towards anticipatory and pre-emptive logics of prevention of radicalization and violent extremism processes following a series of terrorist attacks in EU capitals (Heath-Kelly, 2012; Ragazzi, 2017). According to them, youth and education are seen at the same time as 'at risk' or 'risky' categories and sectors for radicalization and at the forefront of counter-radicalization and CVE responses (Heath-Kelly, 2012; Ragazzi, 2017). This has a myriad of potentially detrimental effects on both (Heath-Kelly, 2012; Ragazzi, 2017).

These policies are now being localized and incorporated into international and national strategies of CVE and counter-radicalization in conflict-affected and post-conflict countries regardless of whether and what type of radicalization and violent extremism is present. However, little research has addressed this recent development as most of the research has focused on the European context. The paper seeks to fill this gap in the section 'Education, de-radicalization and countering violent extremism, 2014-2019', which accounts for a shift and change in forms and priorities of international assistance and intervention to education in conflict-affected and post-conflict countries by linking the development of local policies and strategies to broader shifts within international agendas. In other words, in order to understand shifts in the priorities of international and national actors in education reform and assistance in Kosovo, one needs to go beyond the national context and locate those changing priorities within broader shifts and changes in international peace and security agendas.

\section{Conflict and education in Kosovo}

Kosovo, historically the poorest province in the former Yugoslavia defined by Michel Roux in the early 1990s as a '[v]èritable périphérie de la périphérie' (1992: 238), underwent a war in 1998-99. In the aftermath of the war, Kosovo was administered through the UN Mission in Kosovo (UNMIK), which operated as a transitional, interim administration with unlimited legislative and executive powers, and whose competences were gradually and partially transferred to democratically elected provisional local authorities. The solution to the political status of Kosovo came with the unilateral declaration of independence by Kosovo Albanian leaders on 17 February 2008. ${ }^{5}$

\footnotetext{
${ }^{5}$ Kosovo's political status has been at the core of a long conflict between Kosovo Albanians and Serbs. After the war, the negotiation process between Belgrade authorities and Pristina's provisional government resulted in a deadlock, with Kosovo Albanians becoming increasingly frustrated vs. the international UN mission.
} 
For most of its modern history, Kosovo has been a poor and contested frontier area (Roux, 1992). The issue of development interacting with the ethno-national question was of critical importance for the way the conflict unfolded. However, international actors that intervened in post-war Kosovo chose ethnicity as its main explanatory factor. The Kosovo conflict has always been defined as an intractable one (Strazzari, 2008), whose genealogy has been characterized by a manipulation of and a controversy over different 'national historical truths' (Dogo, 1999). The place of Kosovo in Western cognitive maps is part of the deep-rooted tradition of representation of the Balkan region as an intractable problem awaiting remedial and therapeutical strategies (Woodward, 2007; Montanaro, 2009). The inter-ethnic divide between Kosovo Albanians and Kosovo Serbs considered as the conflict root, has been tackled through the promotion of a form of multiculturalism and protection of minority rights which has been translated on the ground in territorial decentralization along ethnic lines ${ }^{6}$ (Randazzo and Bargués, 2012: 27).

Kosovo's education is directly intertwined with conflict drivers. Education has played a crucial role in the rise and shape of Albanian nationalism. Moreover, the struggle over education and schooling in the Albanian language has represented the primary site of contention between Serbs and Albanians in recent history. In analysing the history of the education/war relationship in the region, education practices seem to have been both constitutive and reproductive of violent and exclusivist discourse. In this context, education has been a root and a proximate cause of the ethno-national conflict (Selenica, 2018).

The conflict over Kosovo's education system during the 1990s dates back to the nationalist campaign inaugurated by Milosevic in 1987, which was finalized with the removal of autonomy and the restriction of political, economic, and cultural rights of the Kosovar Albanian community, as well as the mass dismissal of the Kosovar Albanian teaching staff that refused to teach in Serbian. Kosovar Albanians established an organized parallel system of governance, opting for a non-violent form of resistance. In the sphere of education, this meant that most Kosovar pupils boycotted state classes and attended instead parallel schools, which were typically organized in private houses, garages, and cellars (Selenica, 2018). During the 1990s, the education system became structurally separated along ethnic lines, and was divided between a formal Serbian run system that was boycotted by the vast majority of the population, and a tolerated underground and parallel system run by Kosovar Albanians.

As the next sections will show, an overall logic of stabilization and security has underpinned international interventions in the education sector in post-conflict Kosovo. Despite 'stabilization' featuring in the titles of four recent UN missions, there is no UN-wide interpretation of the term (Gidens, 2019). The UK Stabilization Unit has defined stabilization as an approach:

[w]hich is designed to protect and promote legitimate political authority, using a combination of integrated civilian and military actions to reduce violence, re-establish security and prepare for longer-term recovery by building an enabling environment for structural stability (Gilder 2019: 50).

Intrinsic to this definition, as well as other definitions provided by the USA, is an increasing focus on security and structural stability as pre-conditions to long-term peace. On the ground, it has entailed a greater focus on counter-terrorism within UN peacekeeping operations.

The post-conflict period is divided into two phases not only for analytical purposes, but also because each phase respectively is underpinned by a peculiar logic that reflects broader changes and shifts in the global order and in international agendas of intervention.

\footnotetext{
${ }^{6}$ Under UN legislation, Kosovo's eight communities (i.e. communities whose members belong to the same ethnic, religious, and linguistic group) are Albanians (92\%), Serbs (4\%), and then, in lose order, Turks, Bosniaks, Gorani, Roma, Egyptians, and Ashkali (Krasniqi, 2010: 402).
} 
During the first period between 1999 and 2013, the international community sought to rebuild an education system based on the values of multiculturalism and liberal peace. I argue that this was in line and indeed reflected the main template of intervention in conflict-affected and postconflict promoted by the United Nations and the broader international community between the 1990 s and the early 2000, that is, the liberal peace agenda. Although an attempt to engineer multicultural liberal peace through education was initially advocated by the UN mission and other international actors outside the mission, for stability and security reasons, international actors involved in education reform soon accepted the de-facto ethnically segregated education system that came to be established after the war as a result of local nationalist agendas. In other words, the UN and the broader international community clashed not only with local nationalist actors, but also with its other priorities and agendas that in Kosovo as elsewhere in the 1990s had more to do with stability and security than peace and social transformation.

During the second period between 2014 and 2019, the international community shifted the focus towards youth and education for CVE and radicalization. This reflected broader changes in the logics and agendas of international interventions that, since 9/11 and more sharply after the Madrid and London bombings in 2004 and 2005, have increasingly focused in conflict-affected contexts as well as EU states on tackling terrorism, violent extremism, and radicalization (Heath-Kelly, 2012). The international community in Kosovo, while still maintaining a focus on minority rights, has increasingly focused on the prevention of violent extremism and radicalization processes, following the departure, since 2014, of approximately 400 Kosovo Albanian foreign fighters to join ISIS forces in Syria and Iraq. During this period and in line with EU and UN policies, an 'all-societal approach' in fighting terrorism, violent extremism, and radicalization has entailed the conceptualization of social sectors and actors such as education and students as 'at risk' of radicalization and 'risky' categories within radicalization dynamics but also as potentially at the forefront for the prevention of violent extremism and radicalization (Heath-Kelly, 2012; Novelli, 2017; Ragazzi, 2017). In both phases, international actors have targeted the education sector with superficial strategies and solutions to what were identified as the main problems while avoiding addressing substantial and structural inequalities that underpinned both the conflict and the radicalization of young foreign fighters.

\section{The hybrid governance of education reform in post-war Kosovo}

Different from other post-conflict situations, the international community was not confronted with a formal local government as they engaged in post-conflict educational reform. The UN administration focused on both infrastructural reconstruction and long-term reform (Søbjerg, 2006). The parallel system of education - a centrepiece of Albanian resistance to Milosevic's repressive regime - was sidelined by the newly established UNMIK's Department of Education and Science (DoES) (Sommers and Buckland, 2004: 35).

The reform phase was launched by DoES through the articulation of a strategic initiative called Developing an Education System for Kosovo (DESK), which was composed of international and local multi-stakeholder working groups that addressed systemic and strategic educational issues (Selenica, 2018). The international community considered Kosovo's educational legacy problematic, therefore in need of substantial change (Sommers and Buckland, 2004). Michael Daxner Principal International Officer of the DoES and Principal Administrator of the University of Pristina - attracted considerable levels of funding for education, recruited international consultants, and inaugurated the 'lead-agencies approach', in which renowned international agencies were assigned core tasks within the education system. UNICEF and UNESCO were in charge of curriculum reform; the World Bank focused on quality assurance, management information system support, and school decentralization; the European Commission was in charge of infrastructural reconstruction and vocational training; the Canadian International Development Agency (CIDA) was in charge of teacher training; the Deutsche Gesellschaft für Internationale 
Zusammenarbeit (GIZ) on technical and vocational training (TVET), and the Dutch NGO Spark and later OSCE on higher education and minority education.

A local education expert distinguished between two different international approaches in education reform: the first was sensitive to the local context and the past legacy, whereas the second that prevailed was the one enacted by Michael Daxner. ${ }^{7}$ With the promotion of the 'lead agencies' approach, Daxner ignored and sidelined local capacities. ${ }^{8}$ Outside the UNMIK structures, there was a multiplicity of international governmental and non-governmental agencies - engaged both as donors and implementing partners - whose roles and functions often overlapped or conflicted. The local Ministry of Education, Science, and Technology remained heavily dependent on financial and technical assistance of the international community for more than one decade after the end of war, in particular on management system capacities, decentralization programmes, curriculum development, teacher development, and quality assurance (UNDP, 2013: 38-39).

In the aftermath of war, the international community's attempts to build a pluralist and multiethnic society met with the resistance of local, nationalistic agendas: as a result, post-intervention education reforms reinforced ethnical segregation in a reversed way (Nelles, 2006: 98). By 2000, most of the Albanian students and teachers moved from the parallel system into government schools, whereas Serbs across Kosovo moved from the government buildings into building their own parallel system of education supported and funded by Belgrade. The integration of the Serbian community into a unique education system became a politicized issue that has not been resolved yet. Ethnic separation of the education system throughout the 1990s and the ethnic war between the two communities made post-conflict segregation also a foreign choice (Kostovicova, 2005).

Education for peace in Kosovo: the management of difference through curricula/textbooks reform and education for minorities, 1999-2013.

One of the two main explanatory frameworks for the civil wars in the 1990s emphasized the cultural causes of war in particular ethnic, religious, and cultural differences and identities (Woodward, 2005). The cultural thesis of civil war and violence argued that wars, in particular those in the Balkans in the 1990s, were fought over ethnic and religious diversity and underpinned by ancient ethnic hatreds (Kaufmann, 1996). ${ }^{9}$ At the heart of the UNMIK peacebuilding mission was the objective of managing diversity and difference by building a multicultural state. Difference in Kosovo was institutionalized and protected through a process of decentralization promoted and supported by the international community: the condition for sovereignty and statehood became the accommodation of claims by distinctive identity groups, which - however - sought payoffs and rewards by avoiding connections, exchange, and integration (Monteux, 2006; Randazzo and Bargués Pedreny, 2012). Managing difference through decentralization had a lasting impact on the education system too. In the aftermath of the conflict, the international community focused on two areas of education whose reform was underpinned by the objectives of managing ethnic diversity and fostering a pluralist and multicultural society: curricula reform and education for minorities.

With regards to curricula reform, UNICEF took charge of primary curriculum reform through a process funded by several donors such as Japan and the United Nations Human Security Trust Fund (UNICEF and DoES-UNMIK, 2001). The first reform initiative was the new Kosovo Curriculum Framework, based on Western trends of educational development, in particular,

\footnotetext{
${ }^{7}$ Interview with a local education expert, AAB University, 1 November 2013, Pristina, Kosovo.

${ }^{8}$ Ibid.

${ }^{9}$ According to this argument, frozen medieval hatreds came to the surface as a result of the end of the Cold War and the ideological vacuum that was created in its aftermath. Empirical evidence has contradicted in part the economic and cultural thesis of civil war and even more the distinction between old and new wars (Kalyvas, 2001).
} 
the focus on learner-centred approaches (Tahirsylaj, 2013). In 2002, the local Ministry of Education, Science, and Technology (MEST) took over education reform, including curriculum development, but the role of international actors in the process remained important.

MEST has tried to adopt a single curriculum for all Kosovan communities, with translation in different languages. However, the curriculum in Serbian has been drafted but not issued, and there is no record or statistics on the number of Serb pupils and schools of the parallel system, nor is there a strategy of integration of the Serbian parallel system into the Albanian one (OSCE, 2003, 2006, 2009b).

One of the most contentious aspects in curricula reform has been history curriculum, in particular the period between World War II and the war in Kosovo in 1999. Here too, international initiatives sought to address the historical controversies through joint researches and scholars that were, however, met with local resistance (Nelles, 2006). The battle over Kosovo's history has resulted in competing and exclusivist school curricula (Sommers and Buckland, 2004: 39). Much of the conflict over politics and education in Kosovo has been around different and competing interpretations of Kosovo history by Serbs and Albanians (Dogo, 1999). Although this was a pressing issue in the early years after the war, ${ }^{10}$ and it still remains one of the most contentious ones, interviews conducted fourteen years later confirm that history curricula is less contentious than in the aftermath of the conflict. ${ }^{11}$

An OSCE report argues that while curricula in Kosovo satisfy the educational needs of specific communities, they fail to promote '[m]utual respect, understanding and tolerance' (OSCE, 2009b: 24). OSCE concludes that youth from different communities in Kosovo that are being formed in the current education systems will find it difficult to communicate with each other for lack of a commonly understood language and for lack of a non-divisive and shared history (OSCE, 2009b). According to Montanaro, ' $[\mathrm{T}]$ he language barriers, different school curricula and different ways of teaching history, identity and nationhood risk contribute to a worsening of the inter-ethnic divide' (2009: 12). Indeed, curricula for community-specific 'national' subjects for the most vulnerable Roma, Ashkali, Egyptian, Gorani, Kosovo Croat, and Kosovo Montenegrin communities have not been developed yet (OSCE, 2009b: 1).

Educational access for minority groups was heavily affected by the bifurcation of education during the 1990s - between a formal Serbian system and an Albanian underground - and its extreme fragmentation. UNMIK aimed to develop an education system based on interactive methodologies and new curricular topics that could promote equitable access and mutual understanding among different ethnic groups. For the purpose of multi-ethnic schooling, in the aftermath of war, UNMIK organized shift schemes or shared facilities, targeting particularly the Serbian and Albanian communities. However, this solution did not work either because of the lack of will on the part of the two communities to attend the same schools or for lack of physical security (Nelles, 2006: 102).

OSCE, USAID, and the Dutch NGO Spark have been particularly active in the field of higher education for minorities. ${ }^{12}$ Most of the IOs involved in multicultural projects to education ${ }^{13}$ have addressed one or more education issues of a given community without a comprehensive and trans-community approach. In 2011, MEST supported by the OSCE Higher Commissioner for National Minorities (HCNM) has been developing two textbooks designed for boosting intercultural education: a textbook for learning Albanian as second language for minorities' students and a textbook for civic and intercultural education (MEST, 2011: 29). Although the Bosnian, Turkish, and Roma, Ashkali, and Egyptian (RAE) communities are partially integrated within the Kosovo

\footnotetext{
${ }^{10}$ Sommers and Buckland (2004) highlight that the issue of history was a constant theme in the interviews that were conducted with Kosovar Albanians and Serbs in 2004.

${ }^{11}$ Interview with head of curriculum section, MEST, 12 November 2013, Pristina, Kosovo.

${ }^{12}$ Skype interview with former employee with the Dutch NGO Spark, 21 November 2013; interview with local education expert, AAB University, 1 November 2013, Pristina, Kosovo.

${ }^{13}$ Such as OSCE, Council of Europe, US Embassy, and UNICEF.
} 
system of education, Gorani and Serb communities are not integrated at all (OSCE, 2009a). This suggests that communities seem to be moving gradually on their own separate ways (OSCE, $2009 a$ ). The respect of the rights and interests of minority communities has led to the promotion of decentralization policies along ethnic lines with consequences felt in the fragmented and decentralized education system(s). A fragmented and decentralized education has hampered interaction between different communities and thus the integration of minority groups.

\section{Education, de-radicalisation and countering violent extremism, 2014-2019.}

Countering terrorism, CVE, and addressing the foreign fighters phenomenon have become central concerns for international donors and local actors in the Western Balkans since the rise of the Islamic State is Syria and Iraq in 2014. This shift in focus has also been reflected in Kosovo, in which education together with youth and Muslim authorities and communities have been targeted by strategies and policies CVE and radicalization (Selenica, 2019). This comes as a result of an increased participation of Balkan foreign fighters, in particular from Bosnia Herzegovina and Kosovo in the wars in Iraq and Syria (Augestad Knudsen, 2017). It is estimated that around 400 Kosovo citizens travelled to territories under ISIS rule between 2012 and 2017, most of whom were young males belonging to the 20-30 age group (Kursani, 2015; Hegghammer, 2016; Kursani, 2018). The peculiar socio-economic and demographic features of Kosovo society - a substantial number of male youth in conditions of poverty and marginalization, 43 percentage of the population below 25 years old, youth unemployment at around 57.7 percentage, and low levels of education - have been identified as among the main factors for radicalization in Kosovo (European Commission, 2016; Gjinovci, 2016).

A plethora of local and international actors have been active in the field of preventing radicalization and religious extremism in Kosovo. For a local analyst, the field has become a 'business' that is driven by 'profit.'. International and bilateral donors such as the US, Italian and Dutch embassies, the EU, USAID, British Council, UNDP, IOM, and OSCE, among others, have funded or implemented projects ranging from the creation of referral mechanisms to projects supporting women, media, youth, civil society, etc. ${ }^{15}$ Several interviews confirmed that the main focus from international actors in the coming years is expected to be on youth. ${ }^{16}$

Although a recent study has pointed out to the fact that education does not seem to be a significant driver for radicalization in Kosovo (Kursani, 2018), ${ }^{17}$ poor education has been identified by many donors and national authorities as a driving factor underpinning trajectories of radicalization and violent extremism. Depending on the different stakeholders dealing with the issue, it is either the level of education or its quality that matters. According to recent data, around $80 \%$ of Kosovo foreign fighters have finished secondary school, $8 \%$ elementary school, and $9 \%$ have a university degree (Kursani, 2018). Most of the international actors engaged in education for CVE projects consider radicalization a process driven by a religious identity and education a space where such identity is being shaped and thus the arena where it can also be addressed and prevented.

\footnotetext{
${ }^{14}$ Author's interview with researcher 2, Kosovo Centre for Security Studies, 28 September 2018.

${ }^{15}$ Author's interview with researcher 2, Kosovo Centre for Security Studies, 28 September 2018; author's interview with an investigative journalist, Pristina, 24 September 2018; author's interview with researcher 1, Kosovo Centre for Security Studies, 26 September 2018; author's interview with a local official working with an international organization active in CVE, 26 September 2018.

${ }^{16}$ Author's interview with an investigative journalist, Pristina, 24 September 2018; author's interview with researcher 1, Kosovo Centre for Security Studies, 26 September 2018; author's interview with researcher 2, Kosovo Centre for Security Studies, 28 September 2018.

${ }^{17}$ Kosovo foreign fighters 'have slightly more advanced levels of education than the average Kosovo citizen. Yet their average socio-economic condition is below the Kosovo average; they tend to be poorer and seem to have had less access to opportunities to reach good standards of living compared to the average Kosovo citizen. [...] the unemployment rate among Kosovo originating foreign fighters is double than the Kosovo average' (Kursani, 2018: 3).
} 
The identification of education as a key sector of intervention is clearly seen in the Kosovo's Strategy on Prevention of Violent Extremism and Radicalization Leading to Terrorism 20152020 whereby $40 \%$ of its activities are envisaged to be implemented by the Ministry of Education, Science, and Technology (Office of Prime Minister, 2015). More specifically, education, together with social services, security intelligence, and public administration, is a key sector for early identification of radicalization, particularly, among young men (Office of Prime Minister, 2015: 19); an attractive alternative to radicalism and an arena for critical engagement against violent extremism (Office of Prime Minister, 2015: 20); as well as a key sector for the promotion of tolerance and the provision of global knowledge on religion, among others (Office of Prime Minister, 2015: 23). The Plan envisages the development of awareness sessions and campaigns in and through schools, the establishment of safe environments for sensitive questions and the improvement of psychology and pedagogy services in schools, particularly in the most radicalized areas (Office of Prime Minister, 2015: 22). In the field of education, the implementation plan includes the following key activities for the prevention of violent extremism and radicalization:

Review of historical-educational curriculum, civic education and other respective subjects to emphasize the historical importance of religious tolerance in Kosovo, and to educate young people on what it means to be a good citizen; This activity should also include a review of textbooks and re-training of teachers, as needed (This activity will be implemented in coordination with Public Institutions, including Government, MEST, Municipalities, Municipal Education Departments, parents' community, Religious Communities, field experts, etc.). (Office of Prime Minister, 2015: 22).

\section{Conclusions}

The experience of Kosovo since 1999 suggests that contemporary processes of state and nation building in conflict-affected global peripheries are shaped and moulded by substantial forms of external and international intervention, in which practices of sovereignty and statehood are continuously supervised and negotiated. This is exemplified by the case of education reform in post-war Kosovo analysed for this paper.

The perspective that this paper adopts, in line with this Special Issue's suggestions, is that of looking at the local and the global as mutually constituted ontologically, epistemologically, and methodologically. The paper argues that the same approach needs to be adopted when studying traditionally national sectors such as education. The analysis proposed here suggests that the borders between what is internal from what is international are continuously shifted and negotiated through processes of globalization, international interventionism, and new forms of war, peace, and state making. Education in newborn states is shaped by a variety of international and local actors and the outcome is often a compromise or a clash between different visions and agendas of education as the case study analysed here shows. In the two empirical instances analysed, education is underpinned by a stabilization logic and shaped by global and international dynamics, agendas, and policies for maintaining peace and security.

Far from being the exception of the post-war phase, aspects of exogeneity and hybridity in the governance of education reform have become the norm. The governance of education reform, increasingly beyond and above state sovereignty, suggests that education, once historically central to national building and state formation, is increasingly bound to international imperatives and interests. To follow Turner and Kühn's definition and problematization of the conundrum of international intervention (2016) - which happens so regularly in everyday domestic politics that cannot be regarded as an exception to the discourse of sovereignty - one is led to conclude that being marginal to international statebuilding intervention has not made education an exception to such conundrum. 
Processes such as globalization, war, and international interventions along peripheral regions have challenged the basic unit of analysis - that is, the nation-state. Although traditionally, education policies have been developed within the boundaries of the Westphalian state, national policies are increasingly ' $[\mathrm{a}]$ combination of political forces, social structures, cultural traditions and economic processes entangled in a matrix of intersecting multi-level, multi-scalar (local, national, regional and global) sites and spaces' (Yeates, 2001: 637). The simplification of the levels of analysis along the binary and dichotomous split national/international (local/global) is thus a limitation that needs to be overcome (Dale, 2005). The conception of space and scale as used by Robertson (2012), in which the local, regional, and the global are intertwined and mutually constituted may contribute in such direction. Furthermore, it is much needed to adapt the lenses of IR theory by going beyond a certain methodological nationalism and disciplinary parochialism that has characterized much of the existing literature on war making, state making/unmaking, and international interventions in a globalized world (Leander, 2003). Therefore, as this Special Issue argues, the incorporation of IR and Area Studies into a dialectical and co-operative framework can deepen our analytical perspectives on the international order and help overcome some of the limits associated with methodological nationalism and disciplinary parochialism.

Funding. Part of this study was supported by the Kosovo Foundation for Open Society as part of the project 'Building knowledge of new statehood in Southeast Europe: Understanding Kosovo's domestic and international policy considerations'.

Acknowledgements. I would like to thank the two anonymous reviewers for the helpful comments they provided during the review process, the editor in chief Filippo Tronconi, and the three editors of this Special Issue Silvia D'Amato, Matteo Dian, and Alessandra Russo.

\section{References}

Anderson B (1991) Imagined Communities: Reflections on the Origin and Spread of Nationalism, 2nd Edn. London and New York: Verso.

Augestad Knudsen R (2017) Radicalization and foreign fighters in the Kosovo context. An analysis of the international media coverage of the phenomena, NUPI Working Paper 875, 1-22.

Bevir M (2008) What is genealogy? Journal of the Philosophy of History 2, 263-75.

Boutros-Ghali B (1992) An Agenda for Peace: Preventive Diplomacy, Peacemaking and Peacekeeping. Report of the UN secretary-general, A/47/277-S/24111 (June).

Bush KD and Saltarelli D (2000) The Two Faces of Education in Ethnic Conflict. Florence: UNICEF Innocenti Research Centre.

Dale R (1989) The State and Education Policy. London: Open University Press.

Dale R (1999) Specifying globalisation effects on national policy: focus on the mechanisms. Journal of Educational Policy 14, $1-17$.

Dale R (2000) Globalisation and education: demonstrating a 'common world educational culture' or locating a 'globally structured educational agenda'? Educational Theory 50, 427-48.

Dale R (2005) Globalisation, knowledge economy and comparative education. Comparative Education 41, 117-149.

Dian M (2021) The rise of China between global IR and area studies: an agenda for cooperation. Italian Political Science Review/Rivista Italiana di Science Politiche, 1-16. https://doi.org/10.1017/ipo.2021.31.

Dogo M (1999) Kosovo. Albanesi e Serbi: le Radici del Conflitto. Lungro di Cosenza: Marco Editore.

Duffield M (2008) Global civil war: the non-insured, international containment and post-interventionary society. Journal of Refugee Studies 21, 145-165. https://doi.org/10.1093/jrs/fem049.

European Commission (2016) Kosovo 2016 Report, Brussels.

Gidens A (2019) The effect of 'stabilization' in the mandates and practice of UN peace operations. Netherlands International Law Review 66, 47-73. https://doi.org/10.1007/s40802-019-00128-4.

Gjinovci, R (2016) Kosovo's education system amongst worst in the world, Pristina Insight. 6 December.

Heath-Kelly C (2012) Counter-Terrorism and the Counterfactual: Producing the 'Radicalisationi' Discourse and the UK PREVENT Strategy. BJPIR 15(3), 394-415. https://doi.org/10.1111/j.1467-856X.2011.00489.x.

Hegghammer T (2016) The future of Jihadism in Europe: a pessimistc view. Perspectives on Terrorism 10, 156-170.

Kalyvas S N (2001) “New” and “Old” Civil Wars: A Valid Distinction?. World Politics 54(1), 99-118. https://doi.org/10.1353/ wp.2001.0022.

Kaufmann C (1996) Possible and impossible solutions to ethnic civil wars. International Security 20, 136-75.

Kostovicova D (2005) Kosovo. The politics of identity and space. London: Routledge. 
Krasniqi G (2010) The international community's modus operandi in postwar Bosnia and Herzegovina and in Kosovo: a critical assessment. Südosteuropa 58, 520-541.

Kundnani A and Hayes B (2018) The Globalisation of Countering Violent Extremism Policies. Amsterdam: Transnational Institute.

Kursani S (2015) Report Inquiring into the Causes and Consequences of Kosovo citizens' involvement as foreign fighters in Syria and Iraq, Kosovar Centre for Security Studies, April, Pristina, Kosovo.

Kursani S (2018) Kosovo Report. Western Balkans Extremism Research Forum, April 2018, British Council.

Leander A (2003) Wars and the un-making of states. Taking Tilly seriously in the contemporary world. In Guzzini S and Jung D (eds), Contemporary Security Analysis and Copenhagen Peace Research. London: Routledge.

Martini A (2021) The UN and Counter-Terrorism. Global Hegemonies, Power and Identities. London: Routledge.

McCandless E (2011) Peace dividends and beyond: Contributions of administrative and social services to peacebuilding, United Nations Thematic Review for the Peacebuilding Support Office, New York.

Ministry of Education, Science, and Technology [MEST] (2011) Kosovo Education Strategic Plan 2011-2016. Republic of Kosovo, Pristina, Kosovo.

Montanaro L (2009) The Kosovo Statebuilding Conundrum: Addressing Fragility in a Contested Space. International Alert and Fride Working paper 91, October.

Monteux C (2006) Decentralization: the new delusion of ethnic conflict resolution? International Journal on Multicultural Societies 8, 162-182.

Nelles W (2006) Foundations and fractures of Kosovo's educational system. Towards conflict or peace? In Knudsen TB and Laustsen CB (eds) Kosovo Between War and Peace. Nationalism, Peacebuilding and International Trusteeship. London and New York: Routledge. 96-115.

Novelli M (2017) Education and countering violent extremism: western logics from south to north? Compare 47, 835-851.

Novelli M and Smith A (2011) The Role of Education in Peacebuilding. A synthesis report of findings from Lebanon, Nepal and Sierra Leone. New York: UNICEF.

Novelli M, Higgins S, Ugur M and Valiente O (2014) The Political Economy of Education Systems in Conflict-affected Contexts: A Rigorous Literature Review. Final Report, April.

Novelli M, Lopes Cardozo TMA and Smith A (2017) The 4R framework: analysing education's contribution to sustainable peacebuilding with social justice in conflict-affected contexts. Journal of Education in Emergencies 3, 14-43.

Office of the Prime Minister (2015) Kosovo's Strategy on Prevention of Violent Extremism and Radicalization leading to Terrorism 2015-2020, Republic of Kosovo, September, Pristina, Kosovo.

OSCE (2003) Parallel Structures in Kosovo. Pristina: Organisation for Security and Co-operation in Europe.

OSCE (2006) Parallel Structures in Kosovo 2006-2007. Pristina: Organisation for Security and Co-operation in Europe.

OSCE (2009a) Mid-term report for the feasibility study on community education in Kosovo. Unpublished executive summary draft.

OSCE (2009b) Kosovo non-majority communities within the primary and secondary educational systems. Department of Human Rights and Communities, Pristina, Kosovo.

Paris R (1997) Peacebuilding and the limits of liberal internationalism. International Security 22, 54-89.

Paris R (2004) At War's End: Building Peace After Civil Conflict. Cambridge: Cambridge University Press.

Paris R and Sisk T (eds) (2009) The Dilemmas of Statebuilding: Confronting the Contradictions of Postwar Peace Operations. Abingdon: Routledge.

Paulson J (2008) The 'two faces' today? Research on Comparative and International Education 3, 1-4.

Ragazzi F (2017) Students as Suspect. The challenges of counter-radicalisation policies in education in the Council of Europe member states. Interim report. Council of Europe. Strasbourg.

Raineri L and Baldaro E (2021) The place of Africa in international relations: the centrality of the margins in global IR. Italian Political Science Review/Rivista Italiana di Science Politiche, 1-16. https://doi.org/10.1017/ipo.2021.36.

Randazzo E and Bargués Pedreny P (2012) Peace-building and the loop of liberal multiculturalism: the case of Kosovo. The Western Balkans Policy Review 2 (Summer/Autumn), 27-47.

Richmond O (2011) A Post-Liberal Peace. London and New York: Routledge.

Robertson SL (2012) Researching global education policy: Angles In/On/Out. In Verger A, Novelli M and Altinyelken HK (eds). Global Education Policy and International Development. New Agendas, Issues and Policies. London: Continuum, pp. 33-51.

Robertson SL and Dale R (2015) Towards a 'critical cultural political economy' account of the globalising of education. Globalisation, Societies and Education 13, 149-170.

Rose PM (2007) Supporting Non-state Providers in Basic Education Service Delivery. Paper commissioned by DFID Policy Division, Brighton: Consortium for Research on Educational Access, Transitions and Equity (CREATE). Research Monograph 4/2007.

Roux M (1992) Les Albanais en Yougoslavie. Minorité Nationale territoire et déeveloppment. Paris: Editions de la Maison des Sciences de l'Homme.

Selenica E (2018) Education for whom? Engineering multiculturalism and liberal peace in post-conflict Kosovo. Journal of Southeast European and Black Sea Studies 18, 239-260. 
Selenica E (2019) Countering violent extremism and radicalization in Kosovo: International, state and societal responses and their consequences. In Armakolas I, Demjaha A, Elbasani A and Schwandner-Sievers S (eds), Local and International Determinants of Kosovo's Statehood, Pristina: Kosovo Foundation for Open Society. 67-97.

Sobe NW (2015) All the is global is not world culture: accountability systems and educational apparatus. Globalisation, Societies and Education 13, 135-48.

Søbjerg LM (2006) The Kosovo experiment. Peacebuilding through an international trusteeship. In Knudsen TB and Laustsen CB (eds), Kosovo Between War and Peace. Nationalism, Peacebuilding and International Trusteeship. London and New York: Routledge. 57-75.

Sommers M and Buckland P (2004) Parallel Words. Rebuilding the Education System in Kosovo. International Institute for Educational Planning. Paris: UNESCO.

Strazzari F (2008) Notte balcanica. Guerre, crimine, stati falliti alle soglie d'Europa. Bologna: Il Mulino.

Tahirsylaj A (2013) Educational change in post-war Kosovo: perceptions of Kosovo educators as presented in Shkendija. Interchange 44, 1-13.

Turner M and Kühn FP (eds) (2016) The Politics of International Intervention. The Tyranny of Peace. Oxon and New York: Routledge.

UNDP (2013) Public Pulse Report VI. August, Pristina/Pristina, Kosovo.

UNICEF and DoES-UNMIK (2001) The New Kosovo Curriculum Framework: preschool, primary and secondary education. Discussion White Paper. Pristina, September.

United Nations (2015) United Nations Security Council Resolution 2250, 9 December 2015, S/RES/2250. New York: United Nations.

United Nations (2016) UN Secretary-General's Remarks at General Assembly Presentation of the Plan of Action to Prevent Violent Extremism [As Delivered]. New York: United Nations.

Verger V, Novelli M and Altinyelken HK [eds] (2012) Global Education Policy and International Development: New Agendas, Issues and Policies. London: Bloomsbury.

Visoka G and Musliu V [eds.] (2020) Unravelling Liberal Interventionism. Local Critiques of Statebuilding in Kosovo. Abingdon and New York: Routledge.

Woodward SL (2005) The inequality of violence. On the discovery of civil war as a threat to 'the North' in the 1990s and the debate over causes and solutions. Conference on Difference and Inequality in Developing Societies, Charlotteville, GA, 1-35.

Woodward SL (2007) The Kosovo Quandary: on the International Management of Statehood. FRIDE, March.

World Bank (2005) Reshaping the Future: Education and Post-Conflict Reconstruction. Washington: World Bank.

Yeates N (2001) Globalisation and Social Policy. London: Sage.

Cite this article: Selenica E (2022). Analysing a non-IR field through IR lenses. Education in post-conflict Kosovo. Italian Political Science Review/Rivista Italiana di Scienza Politica 52, 187-202. https://doi.org/10.1017/ipo.2021.52 